\title{
ISKOLAI EGÉSZSÉGNEVELÉS LEHETŐSÉGEI A TESTI-LELKI EGÉSZSÉGMEGÖRZÉS ÉRDEKÉBEN, KÜLÖNÖS TEKINTETTEL A REKREÁCIÓS TEVÉKENYSÉGEK ALKALMAZÁSÁRA
}

\author{
BEREGI ERIKA \\ Miskolci Egyetem Egészségügyi Kar
}

\begin{abstract}
Az iskoláknak mint a másodlagos szocializáció színtereinek hangsúlyos szerepük van az egészségnevelésben, egészségfejlesztésben. A tanulói évek alatt lehetőség adódik formálni a fiatalok attitűdjét az egészséggel mint értékkel kapcsolatban. Kedvezően alakítható egészségmagatartásuk, valamint esély adódhat arra, hogy az elsődleges szocializáció során létrejövő hátrányok leküzdésére, korrekciójára sor kerülhessen. A pedagógusoknak ösztönözni kell a tanulókat arra, hogy legyen igényük a helyes táplálkozásra, mozgásra, a stresszkezelés módszereinek alkalmazására. Mindezek jelentőségét alátámasztja, hogy a magyar lakosság felnőtt- és gyermekpopulációja egészégi állapotának javítására - az ide vonatkozó ismeretek tükrében - óriási szükség van. Az egészséges életmódra való nevelés során kiemelt figyelmet kell fordítani az egészséges táplálkozásra, mozgásra, káros szenvedélyek megelőzésére, a lelki egészségvédelemre, a szabadidő hasznos eltöltésére egyaránt. Az iskolai egészségnevelés, egészségfejlesztés komplex feladat, amely nem nélkülözheti a holisztikus szemléletet. Tanulmányom során a rekreációs lehetőségek széles tárházából adok ízelítőt, mely mindamellett, hogy a tartalmas pihenést, kikapcsolódást szolgálhatja, az egészégmegőrzésben való szerepe sem elhanyagolható. E tevékenységek minél szélesebb körű megismertetése alternatívát adhat a tanulók számára egy egészségesebb életmód választására, kialakítására.
\end{abstract}

\section{Bevezetés}

Felgyorsult, teljesítményorientált világunkban sokszor egy megbetegedés kapcsán kezdünk figyelmet fordítani az egészségünkre mint legfőbb értékre. Az egészség fenntartására, bizonyos betegségek megelőzésére, a testi-lelki jóllét megőrzésére már ősidők óta adottak a lehetőségek. Azonban sok esetben a prevenció háttérbe szorul, a pihenés, a regeneráció, a rekreáció mintegy halasztható tevékenységként jelenik meg, minden mást elötérbe helyezve. A halogatásnak hosszú távon ára van, melyet az egészséges éveinkkel fizetünk meg. Egy egyiptomi közmondás, mely szerint „az egészség korona az ember fején, de csak a beteg 
láthatja meg azt”, pontosan rámutat a jelenségre. Napjainkban a meglévő kihívások mellett a Covid19-világjárvány megjelenése egy jelentős nehézség elé állította az egészségügyet és az oktatási rendszert egyaránt.

Az egészségnevelés helyszínei közül kiemelt szerepe van az iskoláknak mint a másodlagos szocializáció színtereinek. Az iskolában eltöltött idő alatt lehetőség van formálni a tanulók attitűdjét az egészséggel mint értékkel kapcsolatban, kedvezően alakítható egészségtudatos magatartásuk, illetve esély adódhat az esetleges elsődleges szocializáció során tapasztalható hátrányok leküzdésére, korrigálására. Mindezek érdekében a pedagógusok példamutatása, lelkiiismeretes elköteleződése, a szoros szakmai együttműködés, a diákokkal való jó kapcsolat megléte elengedhetetlen.

Az 1995 óta megjelent Nemzeti alaptanterv valamennyi alapdokumentumában megjelenik kiemelt fejlesztési területként, feladatként a testi és lelki egészségnevelés, mely a következő módon van meghatározva:

„Az egészséges életmódra nevelés hozzásegít az egészséges testi és lelki állapot örömteli megéléséhez. A pedagógusok ösztönözzék a tanulókat arra, hogy legyen igényük a helyes táplálkozásra, a mozgásra, a stresszkezelés módszereinek alkalmazására. Legyenek képesek lelki egyensúlyuk megóvására, társas viselkedésük szabályozására, a konfliktusok kezelésére. Az iskola feladata, hogy a családdal együttműködve felkészítse a tanulókat az önállóságra, a betegség-megelőzésre, továbbá a szabályok betartására a közlekedésben, a testi higiénében, a veszélyes körülmények és anyagok felismerésében, a váratlan helyzetek kezelésében. A pedagógusok motiválják és segítsék a tanulókat a káros függőségekhez vezető szokások kialakulásának megelőzésében” (Nemzeti alaptanterv, 2012).

\section{Az életmód és az egészség kapcsolata}

Az iskolai egészségnevelés jelentőségének kiemelése érdekében tisztázni szükséges az egészségi állapotot befolyásoló tényezőket.

Két nagy csoportot vehetünk alapul: a külső és belső tényezőket. Külső tényezőként szerepel a természeti és társadalmi környezet, a belső tényezők része az életmód, a biológiai adottságok, mint például az alkat és személyiségjegyek. Az egészséget meghatározó tényezők közül leggyakrabban négy fö területet emelnek ki (Pikó, 2006).

Az imént említett komponensek közül a lenagyobb hangsúllyal az életmód, ezt követően a genetikai, majd a környezeti tényezők, végezetül pedig az egészségügyi ellátás szerepel. Az egészségi állapotot befolyásoló kockázati tényezők egyfelől nem befolyásolható kockázati tényezők csoportjára, másfelől befolyásolható kockázati tényezők csoportjára oszthatók. Az előbbihez tartoznak többek között az életkor, a nem, a veleszületett genetikai 
adottságok, az utóbbihoz pedig a táplálkozás, a fizikai aktivitás, a szabadidő eltöltése, az élvezeti szerek fogyasztása. (Varga-Hatos \& Karner, 2008)

Lalonde (1974) volt kanadai egészségügyi és népjóléti miniszter által alkotott modell alapján a legnagyobb arányban, mintegy 43\%-ban az életmód, az egészség-magatartás hat az egészségre. A genetikai-biológiai adottságok 27\%-ban, a környezeti tényezők 19\%-ban, az egészségügyi tényezők csupán 11\%-ban vannak hatással, befolyással az egészségi állapotra.

Később módosítás történt McGinnis 2002-es munkája alapján, mely szerint az életmód 40\%-ban, a genetikai, biológiai faktor 30\%-ban, a környezeti tényezők 5\%-ban, társadalmi- gazdasági tényezők 15\%-ban, az egészségügyi ellátás 10\%-ban határozza meg az egészségi állapotot. Az életmód kategóriájába tartoznak az étkezési szokások, a fizikai aktivitás, az alkoholfogyasztás, a dohányzás. A genetikai, biológiai faktorokhoz az életkor, a nem, a fogékonyság, genetikai adottság tartozik. A környezeti tényezők közzé pedig a lakáskörülmények, a levegőszennyezettség, a foglalkozási ártalmak sorolandók (McGinnis, Williams Russo \& Knickman, 2002).

Kiemelendő, hogy az életmódra, illetve az egészségre jelentős befolyással bír a szociális státusz is, mely a társadalmi erőforrásokhoz való hozzáférést határozza meg, az anyagi helyzetnek és a társadalmi kapcsolatoknak megfelelően (Vitrai, \& Mihalicza, 2006).

Látható, hogy az életmód játszik legnagyobb szerepet az egészséget meghatározó tényezők sorában, valamint az is szembetűnő, hogy e komponens az egyén által befolyásolható, tehát adott esetben kedvező irányba módosítható.

Az egészségmegőrzés, egészségfejlesztés lehetőségeinek feltárásához további tisztázandó terület az egészség, valamit a lelki egészség meghatározása. Számtalan egészségdefiníció létezik, melyek az évek folyamán folyamatosan bővültek, módosultak.

A WHO meghatározása szerint az egészség egyik dimenziója a testi egészség, mely magába foglalja az egészségvédő életvezetést, mint például a rendszeres testmozgást, az egészséges táplálkozást, az önkárosító magatartásformák elkerülését. A pszichológiai egészség többek között az általános jóllétet, önmagunk elfogadását, a világos gondolkodási képességet, a tartalmas emberi kapcsolatokat, az intimitás képességét, a nehéz helyzetekben észlelhető erős szociális hálót jelenti. A legújabb WHO-meghatározás alapján a lelki egészség a jóllét állapota, melyben a személy megvalósítja képességeit, meg tud birkózni az élet stresszeivel, produktívan dolgozik, képes hozzájárulni a közösség működéséhez (Kopp \& Pikó, 2006).

A mentális egészség és a mentális jólét alapvető jelentőségủ az egyének, családok, közösségek és nemzetek életminősége, termelékenysége szempontjából, ami értelmes életet, egyben kreatív és aktív állampolgári létet tesz lehetővé az emberek számára. (Európai nyilatkozat a mentális egészségről, 2005) A mentális egészség, valamint a mentálhigiénés problémák megelőzésének, kezelésének, gondozásának, rehabilitációjának támogatása az Európai Unió és az Európai Tanács prioritásai közzé tartozik (Zöld könyv, 2006). 
Az egészségfejlesztés vagy egészségmegőrzés fogalmát Marc Lalone kanadai egészségügyi miniszter alkalmazta először. Abból indult ki, hogy a környezeti hatások, továbbá az egyén életmódja és viselkedése áll a legfőbb halálokok mögött (Naidoo \& Wills, 1999). Az Ottawai Charta az egészségfejlesztést olyan folyamatként határozta meg, amely módot ad az egyéneknek, közösségeknek egészségük fokozott kézbentartására és tökéletesítésére (WHO, 1986). A Dzsakartai nyilatkozat meghatározza az egészségfejlesztés XXI. századi prioritásait, kiemelve az egyén megerősítését, a közösségi kapacitások fejlesztését, ami az iskolai egészségfejlesztés szempontjából jelentős (WHO, 1997).

\section{Iskolai egészségnevelés, egészségfejlesztés}

Az iskolai keretek között történő egészségfejlesztés jogszabályok által meghatározott, kötelezően előírt célokat és tevékenységeket foglal magába az intézmények feladatai között. A Nemzeti alaptanterv megfogalmazása alapján az egészségnevelés a közoktatás kiemelt fejlesztési feladata, melynek az iskolai oktatás valamennyi elemét szükséges áthatnia. Ugyanakkor elő kell segíteni a tantárgyközi kapcsolatok erősítését, a tanítás- tanulás szemléleti egységét (Nemzeti alaptanterv, 2012).

A Köznevelési törvény 2003-as módosítása következtében bekerült új rendelkezés értelmében a nevelési program részeként el kell készíteni az iskola egészségnevelési és környezeti nevelési programját. Ennek tartalmaznia kell az egészségfejlesztéssel összefüggő iskolai feladatokat, a mindennapi testedzés feladatainak megvalósítására szolgáló programokat (2003. évi LXI. törvény).

A nemzeti köznevelésről szóló 2011. évi CXC törvény irányt adott és jelentős segítséget nyújtott a teljes körü iskolai egészségfejlesztés rendszerszerű megvalósításához. A törvény által meghatározott célok között szerepelt többek között egy olyan köznevelési rendszer megalkotása, mely elősegíti a fiatalok harmonikus testi, lelki és értelmi fejlődését (2011. évi CXC. törvény a nemzeti köznevelésről). A nevelési-oktatási intézmények működéséről és a köznevelési intézmények névhasználatáról szóló 20/2012. (VIII.31.) EMMI rendelet a tanulók egészségének, valamint biztonságának védelmével összefüggő feladatokat részletesen tartalmazza.

2004. szeptember 1-től kezdődően a hatályos Közoktatási törvény már azt is előírta, hogy a pedagógiai programok egészségnevelési programokkal legyenek kiegészítve. A korábbi, az Oktatási Minisztérium által 2004-ben kiadott segédlet részletes útmutatást nyújtott az iskolai egészségnevelési, egészségfejlesztési program elkészítéséhez. A kiadvány alapos segítséget biztosít többek között az iskolai egészségfejlesztés módszereinek, a programkészítési folyamat lépéseinek, a segítő kapcsolatok színtereinek, az egészségnevelési program 
megtervezésének vonatkozásában. Ugyanakkor a tanórán kívüli foglalkozások, valamint a mindennapos iskolai testedzés program elkészítéséhez is ajánlást biztosított (Segédlet az iskolai egészségnevelési, egészségfejlesztési program elkészítéséhez, 2004). Mindezek jelentőségét alátámasztja, hogy a magyar lakosság egészségi állapotának javítására az ide vonatkozó ismeretek tökrében óriási szükség van a felnőtt és gyermek populáció tekintetében is. Az egészséges életmódra nevelés során kiemelt figyelmet kell fordítani az egészséges táplálkozásra, mozgásra, a káros szenvedélyek megelőzésére, a lelki egészségvédelemre, a szabadidő hasznos eltöltésére egyaránt. Az egészség megőrzése érdekében biztosítani kell a pihenés és regeneráció lehetőségét, és ehhez szükséges a pedagógusok példamutatása, irányadása.

Az iskoláskorú gyermekek egészség-magatartása elnevezésű, az Egészségügyi Világszervezettel együttműködésben megvalósuló nemzetközi kutatás 2014. évi felméréséről készült jelentésben olvashatunk többek között a fizikai aktivitás és a képernyőhasználatról. A fizikai aktivitást legalább 60 perc időtartamú és közepes és erős intenzitású mozgás heti gyakoriságával és az erőteljes testedzés gyakoriságával és időtartamával jellemezték. A vizsgált 11 és 18 éves fiatalok alig ötödéről mondható el, hogy eleget mozog napi szinten. Jellemzően a lányoknak még a hatoda sem teljesíti az ajánlott intenzitást és napi mennyiséget. Ugyanez a fiúk több mint a negyedére jellemző. A játékcélból végzett napi több órás számítógépezés tanítási napokon tízből négy tanulóra jellemző, hétvégén pedig tízből hat tanulóra. A nem játékcélú számítógép-használat, mint például a chatelés, internetezés, házi feladat elkészítése, a lányok esetében népszerủbb, mint a fiúknál. Azonban elmondható, hogy az elmúlt nyolc évben mindkét nem tekintetében növekedett a számítógépet sokat használók aránya. Az eredmények tükrében a mozgási kedv, a motiváció serkentésére lenne szükség a fiatalok körében.

Indokolt lehet a közoktatási és felvételi rendszer átalakítására, egészségnevelő programok, stratégiák további fejlesztésére, ingyenes sportszakkörök létrehozására, ifjúsági tömegsport fejlesztésére, fizikai környezet, infrastruktúra javítására figyelmet fordítani. A fizikailag passzív elfoglaltságok csökkentére vonatkozó hatásos beavatkozások csak együttesen, családon és iskolán keresztül érhetőek el. (Németh, 2014)

Az iskolai egészségnevelés, egészségfejlesztés komplex feladat, amely nem nélkülözheti a holisztikus szemléletet. Tanulmányom további részében a rekreációs lehetőségek széles tárházából adok ízelítőt, mely mindamellett, hogy a tartalmas pihenést, kikapcsolódást szolgálhatja, egészégmegőrzésben való szerepe sem elhanyagolható. 


\section{A rekreáció meghatározása}

A latin eredetű „rekreáció” szó üdülést, pihenést, felfrissülést jelent (Bakos, 2002). A köznyelvben leginkább a szabadidő-kultúrával azonosítják. A rekreáció önkéntes részvétel olyan típusú szabadidő-tevékenységben, amely az egyén számára értelmes és élvezetes (Kovács, 2004).

A kikapcsolódásról a Didactica magna-ban, Commenius 1657-ben megjelent fó művében is olvashatunk. Minden héten volt egy olyan nap a tanítás során, amikor a tanulók kirándultak, játékos feladatokat kaptak. A rekreáció mint iskolai szünidő jelenik meg, amikor a gyerekek mással foglalkoznak, nem tanulnak, hanem kipihenik magukat (idézi Kovács, 2004). A rekreáció sokféle megfogalmazásával találkozhatunk napjainkban, a teljeség igénye nélkül kiemelek néhány, gyakran idézett definíciót.

Fritz Péter (2011) komplex megfogalmazása alapján „a rekreáció a szabadidőben, a tevékeny pihenés érdekében végzett minden olyan kulturális, társas, játékos és mozgásos tevékenység, melyet a napi fó elfoglaltság által okozott fáradtság, feszültség feloldása, a testi-lelki-szellemi teljesítőkészség és -képesség helyreállítása, fokozása érdekében tesz az ember”.

Ábrahám Júlia (2010) megfogalmazása szerint a rekreáció olyan szabadidős magatartásformák összessége, melynek célja és eredménye a közérzet javulása. A szabadidős tevékenység önmagában nem szerepel rekreációként, csak annak potenciális lehetőségeként.

A feltárt definíciók legnagyobb részében megtalálható, hogy szabadidőben végzett tevékenységről van szó, valamint hogy a rekreációs tevékenységek végzése a közérzet javulását eredményezi. Kovács Tamás Attila (2007) megfogalmazásában a rekreáció társadalmi funkciójaként értelmezi a munkaképesség újratermelését, valamint egészségmegőrző, egészségfejlesztő szerepét is kiemeli. Néhány szerző (Ábrahám, Bárdos, 2014) alapján nem sorolható az egészségmegőrzés céljából végzett testmozgás a szabadidős tevékenységek körébe, mivel nem felel meg a szabadidőben, szabad választásból végzett kritériumnak. Ennek megfelelően rekreatív többlettről vagy félszabadidőről lehet szó. Dumazediernek köszönhetően bevezetésre került a „félszabadidő” fogalma, amellyel a nélkülözhetetlen társadalmi, családi kötelezettségek óráit különbözteti meg, a kedvtelésből eltöltött „szabad” időtől. (Fritz, 2019) Lényeges a rekreatív többlet pontosítása, meghatározása, mely a nem szabadidős tevékenységeinkben keletkező rekreációs hatásokat jelenti. A többlet megjelenhet a kedvvel végzett munkában, mint például fözés, takarítás, valamint akár a fiziológiás szükségletek kielégítése során, értendő ezalatt pl. étkezés, fürdés (Kovács, 2007, Fritz, 2011, 2019).

A rekreációval foglalkozó tanulmányok jelentős része kiemeli a testmozgás, a sport jelentőségét, egészségmegőrzésben betöltött szerepét, melyet jól tükröz az alábbi megfogalmazás, mely szerint a mozgásos rekreáció célja az egészség megőrzése, fejlesztése, a testi-lelki jólét megteremtése (Fritz, 2011). 
A rekreáció egészségre gyakorolt pozitív hatásait befolyásolják a sokszínű tevékenységek típusai, főbb jellemzői. A szakirodalom többségében két fö részt különít el, melyek a fizikai vagy mozgásos, valamint a szellemi rekreációt foglalják magukba. Ezeken belül többféle alcsoportot figyelhetünk meg. A fizikai rekreáció magába foglalja azokat tevékenységeket, melyekben a testmozgásnak van szerepe.

Szellemi rekreációval kevés hazai és nemzetközi tanulmány foglalkozik. Meghatározására több definíció is létezik, azonban egyik sem tekinthető 100\%-osan pontosnak. Nagyon általános megfogalmazásban ide sorolható valamennyi olyan szabadidős tevékenység, amely elsősorban nem a fizikumot veszi igénybe. A szellemi rekreációnak négy fó csoportját lehet meghatározni, kulturális, társasági-egyéni, természeti és kiegészítő és relaxációs eljárások. A kulturális tevékenységek közzé tartoznak a művészeti, a gyűjtő, a szellemi programok, a társasági-egyéni tevékenységek, amelyek magukba foglalják a játékokat, összejöveteleket, sporttevékenységeket, a szurkolást. A természeti kategóriába a természet tanulmányozása, a természeti értékek gyüjtése tartozik. Kiegészítő és relaxációs eljárások közé sorolta a szerző a szolárium, a fizioterápia, a hőkamrák és fürdőtípusok, a masszázs, a progresszív izomlazítás, az autogén tréning, a meditáció, a légzőgyakorlatok, az aromaterápia, a zenehallgatás mint szellemi rekreációs tevékenységek formáit. (Fritz, 2015).

\section{Rekreáció és az egészségmegőrzés}

A fizikai aktivitás és az egészség közötti kapcsolat feltárása az elmúlt néhány évtized epidemiológiai kutatásainak meghatározó területe volt. Ezen kutatások ismereteinek birtokában ma már egyértelműen látható a rendszeresen végzett fizikai aktivitás szervezetre gyakorolt pozitív, preventív, protektív hatása. Világszerte a legnagyobb mortalitást és morbiditást a szív- és érrendszeri kórképek, a daganatos betegségek, a cukorbetegség, a mentális zavarok, továbbá a krónikus légzőszervi problémák okozzák.

Az élethosszig tartó, rendszeres fizikai aktivitás mint az egészséget meghatározó egyik fó tényező ezen betegségek megelőzésében kiemelt szerepet játszik. (WHO, 2008)

Egy 2003-ban megjelent tanulmányban kimutatták tíz éves időtávot vizsgálva, hogy ha egy dollárt áldoznak egy ember mozgására, kettő-öt dolláros megtérülés várható (Staines, Prince \& Oliver, 2003). Az Egészségügyi Világszervezet „Health and development through physical activity and sport” címmel kiadott 2003-as dokumentumában olvasható, hogy az egészségügynek 2,3 dollár megtakarítást jellent minden fizikai aktivitásba fektetett dollár. (WHO, 2003)

Szintén a szabadidősport társadalom szempontjából való hasznosságát támasztja alá a 2005-ben megjelent, a Sport a XXI. Nemzeti Sportstratégiáról című háttéranyagban olvasható nemzetközi kutatási eredmények becslése. Ennek alapján megállapításra került, 
hogy a magyar sportoló lakosság arányának 16\%-ról 24\%-ra való emelkedése a táppénzkiadások tekintetében 6 milliárd forint megtakarítást eredményezne (OGY határozata a Sport XXI. Nemzeti Sportstratégiáról, 2005).

Tudományos kutatásokkal alátámasztott, hogy a rendszeres fizikai aktivitás csökkenti a vérnyomást, a szív- és érrendszeri betegségek előfordulási gyakoriságát, valamint a cukorbetegség kialakulásának kockázatát. A rendszeres testmozgás fejleszti a csont- és izomrendszert, ezáltal megelőzve a mozgásszervi megbetegedéseket. Az USA-ban egy tíz évet átfogó megfigyelés során az alacsony intenzitású fizikai aktivitást folytató egyének tekintetében, nők és férfiak között egyaránt, háromszor magasabb volt az elhízottak aránya, mint az aktív tevékenységet végző kontrollcsoport esetében (Téglásy, 2006).

Bognár József (2019) rávilágított arra, hogy a rendszeres, az életkornak és a képességszinteknek megfelelő fizikai aktivitás amellett, hogy képesség- és egészségfejlesztő funkcióval bír, dinamikusan hozzájárul a személyiség formálásához és alakításához, valamint elősegíti a gyermekben rejlő képességek optimális kibontakozását. Fügedi, Bognár és Kovács (2019) kutatásuk során vizsgálták a szülői minta szerepét a sportolási szokásokban és a testnevelés megítélésében. Egy vidéki kisváros 10-12 éves tanulóit és szüleit kérdezték meg sportolási szokásaikkal, fizikai aktivitásukkal és a testneveléssel kapcsolatban. Elsődleges szándékuk az volt, hogy képet kapjanak a tanulók és szüleik gondolkodásáról, szokásairól a rendszeres testmozgás tekintetében. Megállapították, hogy a szülői példamutatásnak jelentős szerepe van a gyermekek személyiségének formálásában, a fizikailag aktív magatartás kialakításában. Mindezeknek elsődleges beavatkozási felületnek kell lennie a fiatalok egészségi, fizikai állapotán javítása érdekében.

Az Eszterházy Károly Főiskola Sporttudományi Intézetének munkatársai által 2012-ben végzett szekunder kutatáson alapuló tanulmánya áttekinti a hazai és nemzetközi kutatások fitnesztrendjeit a rekreációban. Megfogalmazzák, hogy fontos szempont a rekreációban az egészség megőrzése, a munkaképesség megtartása, valamint a fizikai fitneszszint, a fizikai teherbíróképesség növelése. Bemutatták többek között a zumbát és más zenés mozgásformákat, amelyek egészségre gyakorolt hatásukat tekintve egyrészt zsírégető hatásúak, másrészt az izomtónus, valamint az állóképesség javulását eredményezték. Ismertették a jógát, ami hatásos a lelki, a szellemi, továbbá a testi egészség megtartásában egyaránt. Ismertették a Boot Camp speciális gyakorlatait, melyek fejlesztik a fizikai erőt, az állóképességet, izomtömeg-növelő és zsírégető hatásúak; a fit-ball traininget, mely alkalmas a fittségi szint és a jó közérzet megtartására. A tanulmányban megfogalmazták, hogy a leendő sportszervezőknek, rekreációs szakembereknek nélkülözhetetlen ismerni a fitnesztrendeket, hogy a gyermekeket és felnőtteket motiválni tudják a rendszeres testmozgásra, fittségi szintjük javítására. (Müller et al., 2012)

Kovács Klára (2014) Boldogító mozgás címü tanulmányában bemutatta a sportolás hatását a partiumi hallgatók szubjektív jóllétére, lelki edzettségére és egészségének 
önértékelésére. Megállapította, hogy a verseny- és szabadidő-sportolók szignifikánsan magasabb rezilienciával, valamint szubjektív jólléttel jellemezhetőek, szemben a nem vagy alkalmilag sportoló társaikkal. Az egészség önértékelésének vonatkozásában a szabadidő- sportolók között találta legnagyobb arányban a magukat egészségeseknek érzőket. A lineáris regressziómodellek alapján a lelki edzettségre, szubjektív jóllétre csak a verseny- és szabadidősportoknak van pozitív hatása.

A szabadidőben végzett mozgásos tevékenységek széles lehetőségei közül a nordic walking egészségre gyakorolt hatásai tekintetében is végeztek kutatásokat.

Almádi és László (2010) által végzett vizsgálat célja volt a nordic walking egészségre gyakorolt pozitív hatásának feltárása. A vizsgálat mintáját 114 aktív nordic walkingot végző egyén tette ki. Az egészségi állapot önértékeléséből a szerzők arra következtettek, hogy a megkérdezettek mind nagyon jó egészségi állapotban vannak. A heti gyakorisággal mozgó csoport szignifikánsan kevésbé értékelte negatívan egészségi állapotát, mint a havi gyakorisággal sportoló csoportok.

Nemzetközi tanulmányok is alátámasztják, hogy a rendszeres testmozgásnak szerepe van a II. típusú diabétesz kialakulásának megelőzésében. Gunn és munkatársai (2005) rávilágítottak arra, hogy bármely fizikai aktivitás gátló hatásként szerepel az inzulinrezisztencián alapuló cukorbetegség kialakulásában, illetve jótékony hatású a kardiovaszkuláris megbetegedések vonatkozásában.

A testi egészség megőrzése, a betegségek elkerülése mellett a lelki egészség megőrzése is fokozott figyelmet igényel. Napjainkban a mentális problémák megsokszorozódása figyelhető meg, a mentális megbetegedések száma globálisan emelkedik. Az Európai Unió és a WHO által közösen kidolgozott Zöld Könyv felhívja a figyelmet a mentális betegségekre, és társadalmi szintű lépéseket ajánl (Európai Közösség Bizottsága, 2006).

Szabadidőben végzett rendszeres testedzés a fizikai állapotra gyakorolt kedvező hatása mellett a mentális és pszichés állapotra is pozitív hatással van. Segíti az egyént a stresszel való megküzdésben, csökkenti a szorongást. A sport pozitív irányba mozdítja az egyén megjelenését, ami hozzájárul az önértékelés növekedéséhez. Azoknak az embereknek, akik szabadidejüket fizikailag aktívan töltik el, a testi énképük megítélése jobb lesz, ez pedig alacsonyabb szorongással és depresszióhajlammal jár (Boros \& Kalmárné, 2011).

Figyelemreméltó összefüggést mutatott be a Hungarostudy 2002 országos reprezentatív vizsgálata. Az eredmények tükrében megállapítható, hogy az életvitelbe beágyazott rendszeres testmozgással élők jobb életminőséggel rendelkeznek, az inaktív társaikkal szemben előnyösebb helyzetben vannak a lelki egészség, a depresszió, valamint a vitális kimerültség területi vonatkozásában is. (Gémes, 2006)

A rendszeres testedzés pszichés, szomatikus és pszichoszomatikus hatásaival kapcsolatban sok hazai és nemzetközi szakirodalom született. A fizikailag aktív fiatalok egészségesebben 
élnek, szabadidejüket hasznosabban töltik (Pate et al., 1996, Asszman, 1997). Az egészség megőrzésének, a betegségek megelőzésének, valamint az egészség-magatartás, illetve a kognitív, affektív és szociális képességek vizsgálatai is jellemzően a mozgásos rekreációhoz kapcsolódnak.

A szellemi rekreáció vonatkozásában azonban kevés tanulmány készült. Jellemzően a szerzők a szellemi rekreáció fogalmát, rendszertani megközelítését mutatják be (Fritz et al., 2013). A továbbiakban a sokrétủ szellemi rekreációs tevékenységekkel kapcsolatos kutatások eredményeire mutatok rá, melyek bizonyítják e tevékenységek testi-lelki egészséget érintő pozitív hozadékát. Mindezek amellett, hogy tartalmas szabadidő-eltöltéshez vezetnek, testi-lelki-szellemi jóllétet is eredményeznek.

A természetben töltött idő egyénre gyakorolt pozitív hatásáról bőven találunk szakirodalmat. Arra is van már bizonyíték, hogy a természetjárás mellett a madárvilág megfigyelése is jótékony hatást gyakorol a mentális egészségre. Az Exeteri Egyetem kutatói különböző nemzetiségű, életkorú és anyagi hátterű embereket vizsgáltak, és megállapították, hogy a madarakkal töltött idő segítséget nyújthat a szellemi egészségük karbantartásában (Cox et al., 2017).

Fodor és Szilágyi (2014) a wellness mint egészségmegőrző projekt lehetőségeit a régiók fejlesztésében fogyasztói primer adatok tükrében mutatják be. A vizsgálat aktualitását adta, hogy az egészségtudatosság napjainkban egyre nagyobb hangsúlyt kap, egyes fogyasztói csoportok magatartása e tekintetben fokozatosan erősödik. Az egészségességre való törekvés ez esetben nemcsak a táplálkozásra, a testmozgásra, hanem a szabadidő eltöltésére is vonatkozik, annak motivációi között megjelenve (Szira \& Lajos, 2005). A wellness-szolgáltatások fejlesztése fellendülést hozhat azoknak a településeknek, amelyek a termálvizeknek, a gyógyvizeknek vagy egyéb természeti adottságaiknak köszönhetően jelentős szerepet tudnának betölteni a megelőzésben, egészségfejlesztésben (Árpási, 2014). Fodor és Szilágyi (2014) vizsgálatának fó célja az egészségmegőrzés és a wellness fogyasztói megítélésének kutatása, elemzése volt. Az eredmények rávilágítottak arra, hogy a megkérdezettek jövedelmük legnagyobb részét és a legtöbb figyelmet a helyes táplálkozásra fordítják, ugyanakkor viszonylag kevesebb időt szánnak szellemi kikapcsolódásra, a rendszeres meditáció, masszázs, szauna sem szerepel a mindennapi életük részeként.

\section{Összegzés}

Áttekintő tanulmányom során az iskola egészségnevelési feladataira, lehetőségeire fókuszáltam, kiemelve a rekreációs lehetőségeket a testi és lelki egészségmegőrzésben betöltött szerepükkel kapcsolatban. Felgyorsult, teljesítményorientált világunk, a technika gyors fejlődése, az újabb és újabb megbetegedést okozó tényezők megjelenése, a tanulók változó 
és nem minden esetben tartalmas és egészséges szabadidős szokásainak megjelenése kihívás elé állítja a nevelési-oktatási folyamatban részt vevő szereplőket.

Az iskoláknak mint a másodlagos szocializáció színterének az egészségnevelési tevékenységek tekintetében kitüntetett szerepe van. Az itt eltöltött idő alatt lehetőség van formálni a tanulók attitűdjét az egészséggel mint értékkel kapcsolatban.

Kedvezően alakítható egészségtudatos magatartásuk, esély adódhat az elsődleges szocializáció során tapasztalható esetleges hátrányok leküzdésére, korrigálására. A rekreációs tevékenységek széles tárházának megismertetése az iskolások körében egy kiváló lehetőség lehet egy tudatosabb, egészségesebb generáció felnevelésének elősegítésében.

\section{Felhasznált irodalom:}

Ábrahám, J. (2010). Rekreációs alapok. (Letöltve, 2020. 04. 14). https://atletikamagazin. files.wordpress.com/2014/12/rekreacios-alapok.pdf

Ábrahám, J., \& Bárdos, Gy. (2014). Szabadidő és Rekreáció. Kultúra és Közösség. 5. (1). Almádi., K., \& László, Z. (2010). Nordic walking az egészség megőrzésében.

(Letöltve: 2010. 11. 15). http://epa.oszk.hu/00900/00997/00015/pdf/EPA00997_ Letunk_2010_04_099-116.pdf

Árpási, Z. (2014). Wellness turisztikai szolgálatatások fejlesztésének lehetőségei a Délalföldi régióban. Doktori értekezés, Szent István Egyetem Gazdálkodási- és Szervezéstudományok Doktori Iskola, Gödöllő. 11-39.

Aszmann, A. (1997). Iskolás gyermekek egészségmagatartása 1986-1993. Anonymus Kiadó, Budapest.

Bakos, F. (2002). Idegen kifejezések és szavak szótára. Második, átdolgozott kiadás. Akadémiai Kiadó, Budapest.

Bisebach, G., Bodlaj, G., Sedlak, M., Pieringer, H., \& Kiesling, G. (2009). Exercise program for older patients with insulin- treated type 2 diabetes, Zeitschrift für Gerontologie und geriatre. DOI 10. 1007/s00391-0048-2.

Bognár, J. (2019). A testnevelés értékorientációja. Új Pedagógiai Szemle. 69 (3-4). 100-108.

Boros, Sz., \& Kalmárné Rimóczi, Cs. (2011). A szabadidő-eltöltési szokások testi énképre gyakorolt hatásai. Kalokagathia. 49 (2-4), 118-128.

Cox, D.T.C., Shanahan, D. F., Hudson, H. L., Plummer, K. E., Siriwardena, G. M., Fuller, R. A., Anderson, K., Hancock, S., \& Gatson, K. J. (2017). Doses of Neighborhood Nature: The Benefits of Mental Health of Living with Nature. Bio Science, 67(2), 147-155. https://doi.org/10.1093/biosci/biw173 
Európai Közösség Bizottsága (2006). Zöld Könyv. A lakosság mentális egészségének javítása.

Az Európai Unió mentális egészségi stratégiájának kialakítása 2005. Budapest.

Európai nyilatkozat a mentális egészségről (2005). Helsinki. WHO Európai Miniszteri Konferencia a mentális egészségről.

Fodor, M., \& Szilágyi., T. P. (2014). A wellness, mint egészségmegőrző projekt lehetőségei a régiók fejlesztésében fogyasztói primer adatok tükrében. (Letöltve: 2020. 11. 10.) http://kgk.uniobuda.hu/sites/default/files/13_FodorMonika_SzilagyiTiborPal.pdf

Fritz, P. (2011). Rekreáció mindenkinek I. Mozgásos rekreáció. (2. javított, bővített kiadás). Bába Kiadó, Szeged.

Fritz, P., Szatmári Z., \& Plachy, J. (2013). A szellemi rekreáció fogalma és rendszertana. (Letöltve: 2020. 04. 30.) http://real.mtak.hu/67194/1/2013\%2033\%20a\%20reki\%20 fogalma.pdf https://doi.org/10.21486/recreation.2013.3.3.1

Fritz, P. (2015). Szellemi rekreáció - Rekreáció mindenkinek II. Dialog Campus Kiadó, Budapest.

Fritz, P (2019). Alapfogalmak és jelentéseik rekreáció területén. Rekreáció mindenkinek III. Miskolci Egyetem Kiadó.

Fügedi, B., Bognár, J. \& Kovács, T. L. (2019). A szülői minta szerepe a sportolási szokásokban és a testnevelés megítélésében. (Letöltve: 2020. 11. 10.)

http://real.mtak.hu/108185/1/F\%C3\%BCgedi.pdf

https://doi.org/10.33040/ActaUnivEszterhazySport.2019.1.47

Gémes, K. (2006). Sport és életminőség. In Kopp, M., Kovács, M. E. A magyar népesség életminősége az ezredfordulón. Semmelweis Kiadó, Budapest. 167-180.

Gunn, S. M., Brooks, A. G., Withers, R. T., Gore, CH. J., Plummer, J. L., \& Cormack, J. (2005). The energy cost of household and garden activities in 55-to 65 year old males. European Journal of Applied Physiology 2005(94). 476-486.

https://doi.org/10.1007/s00421-004-1302-3

Kopp, M., \& Pikó, B. (2006). Az egészséggel kapcsolatos életminőség pszichológiai, szociológiai és kulturális dimenziói. In Kopp, M., Kovács, M. E. (szerk.). A magyar népesség életminősége az ezredfordulón. Semmelweis Kiadó, Budapest.

Kovács, K. (2014). Boldogító mozgás. A sportolás hatása a partiumi hallgatók szubjektív jóllétére, lelki edzettségére és egészségének önértékelésére. (Letöltve: 2020. 11. 10). http://epa.oszk.hu/02900/02943/00061/pdf/EPA02943_kapocs_2014_2_02-13.pdf Kovács, T. A. (2004). A rekreáció elmélete és módszertana. Fitness Kft., Budapest.

Kovács, T. A. (2007). A rekreáció fóbb irányzatai. Civilizációs kihívások, rekreációs válaszok. Magyar Sporttudományi Szemle. 8. (30). 3-12. 
Lalonde, M. (1974). A new perspective on the health of Canadians. A working document. Ottawa: Government of Canada. (Letöltés: 2020. 11. 10). http://www. phac-aspc.gc.ca/ph-sp/pdf/perspect-eng.pdf

McGinnis, JM., Williams Russo, P. \& Knickman, JR. (2002). The case for more active policy attention to health promotion. HealthAffairs (Millwood) Mar-Apr, 21(2), 78-93.

https://doi.org/10.1377/hlthaff.21.2.78

Müller, A., Bíró, M., Hídvégi, P., Váczi, P., Plachy, J., Juhász, I., Hajdú, P., Seres, J. (2012). Fitnesz trendek a rekreációban. (Letöltés: 2020. 11. 21). https://www.researchgate. net/publication/311614601_FITNESZ_TRENDEK_A_REKREACIOBAN_ FITNESS_TRENDS_IN_RECREATION

Naidoo, J., \& Wills, J. (1999). Egészségmegőrzés. Gyakorlati alapok. Medicina Kiadó, Budapest.

OGY határozata a Sport XXI. Nemzeti Sportstratégiáról (2007). (Letöltés: 2020. 11. 20.) http://kobanyasc.hu/docs/07sportstrategia.pdf

Németh, Á. (2014). Fizikai aktivitás és képernyőhasználat. In. Egészség és egészségmagatartás iskoláskorban. Az iskoláskorú gyermekek egészségmagatartása elnevezésü, az Egészségügyi Világszervezettel együttmüködésben megvalósuló nemzetközi kutatás 2014. évi felméréséről készült nemzeti jelentés. NEFI.

Pate, R. R., Heath G. W., Dovda M., \& Trost S. G. (1996). Associations between physical activity and other health behaviors in representative sample of US adolescents. Am J Public Health, 86. 1577-1581. https://doi.org/10.2105/AJPH.86.11.1577

Pikó, B. (2006). Lelki egészség a modern társadalomban. Akadémiai Kiadó, Budapest.

Varga-Hatos, K. \& Karner, C. (2008). A lakosság egészségi állapotát befolyásoló tényezők. Egészségügyi Gazdasági Szemle, 2.

Szira, Z., \& Lajos, A. (2005). Health Consciousness in the Life Style and Scale of Values of the Hungarian Young People. In Annals of the Polish Association of Agricultural and Agribusiness Economists . 7(6), 2-16.

Téglásy, Gy. (2006). Táplálkozás + Sport = Egészség. OSEI, MOB, Budapest.

Vitrai, J., \& Mihalicza, P. (2006). Egészségi állapot. In Kolosi, T., Tóth, I. Gy., Vukovich, Gy. (szerk.). Társadalmi riport 2006. Budapest. TÁRKI. 138-150.

Zöld Könyv (2005). A lakosság mentális egészségének javítása. Az Európai unió mentális egészségügyi stratégiájának kialakítása. Európai Közösség Bizottsága, Budapest.

World Health Organisation (1986). Az Ottawai Egészségfejlesztési Charta. Nemzetközi Egészségfejlesztési Konferencia. Ottawa, 1986. november 17-21. In Az egészségfejlesztés alapelvei. Az egészségfejlesztés alapvető nemzetközi dokumentumai. Országos Egészségfejlesztési Intézet, Budapest. 9-14. 
World Health Organisation (1997). Dzsakartai Nyilatkozat. Egészségmegőrzés a XXI. Században. Dzsakarta, 1997. július. In Az egészségfejlesztés alapelvei. Az egészségfejlesztés alapvető nemzetközi dokumentumai. Országos Egészségfejlesztési Intézet, Budapest. 29-34.

World Health Organisation (2008). 2008-2013 Action plan for the global strategy for the prevention and control of noncommunicable diseases. Genova. (Letöltés: 2020. 10. 12). https://www.who.int/nmh/Actionplan-PC-NCD-2008.pdf

\section{Oktatási dokumentumok, jogszabályok}

110/2012. (VI. 4.) Korm. rendelet a Nemzeti alaptanterv kiadásáról, bevezetéséről és alkalmazásáról. Magyar Közlöny Magyarország hivatalos lapja 66. szám. (Letöltés: 2021. 02. 10.)

https://ofi.oh.gov.hu/sites/default/files/attachments/mk_nat_20121.pdf

2003. évi LXI. törvény a közoktatásról szóló 1993. évi LXXIX. törvény módosításáról (Letöltés: 2021. 02. 08.)

https://mkogy.jogtar.hu/jogszabaly?docid=a0300061.TV

2011. évi CXC. törvény a nemzeti köznevelésről (Letöltés: 2021. 02. 08.)

https://net.jogtar.hu/jogszabaly?docid=a1100190.tv

20/2012. (VIII.31.) EMMI rendelet a nevelési-oktatási intézmények működéséről és a köznevelési intézményke névhasználatáról (Letöltés: 2021. 01. 20.)

https://net.jogtar.hu/jogszabaly?docid=a1200020.emm

Segédlet az iskolai egészségnevelési, egészségfejlesztési program elkészítéséhez, 2004. (Letöltés: 2021. 02. 08.)

http://www.nefmi.gov.hu/kozoktatas/egeszsegfejlesztes/segedlet-iskolai 